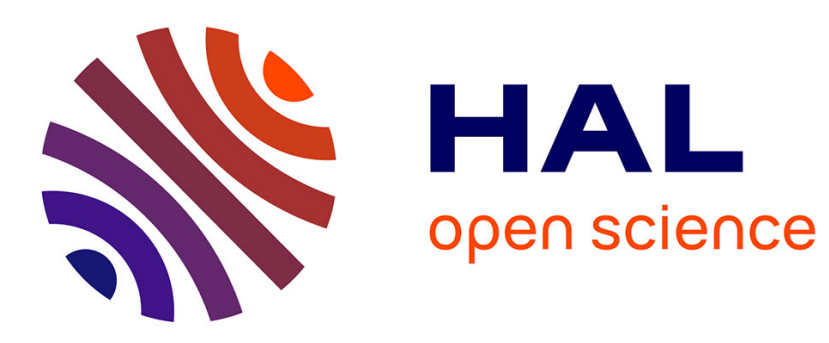

\title{
Illegal gold miners in French Guiana: a neglected population with poor health
}

Maylis Douine, Emilie Mosnier, Quentin Le Hingrat, Charlotte Charpentier, Florine Corlin, Louise Hureau, Antoine Adenis, Yassamine Lazrek, Florence Niemetsky, Anne-Laure Aucouturier, et al.

\section{To cite this version:}

Maylis Douine, Emilie Mosnier, Quentin Le Hingrat, Charlotte Charpentier, Florine Corlin, et al.. Illegal gold miners in French Guiana: a neglected population with poor health. BMC Public Health, 2017, 18 (1), pp.23. 10.1016/S0140-6736(10)62169-1 . inserm-01566314

\section{HAL Id: inserm-01566314 https://www.hal.inserm.fr/inserm-01566314}

Submitted on 20 Jul 2017

HAL is a multi-disciplinary open access archive for the deposit and dissemination of scientific research documents, whether they are published or not. The documents may come from teaching and research institutions in France or abroad, or from public or private research centers.
L'archive ouverte pluridisciplinaire HAL, est destinée au dépôt et à la diffusion de documents scientifiques de niveau recherche, publiés ou non, émanant des établissements d'enseignement et de recherche français ou étrangers, des laboratoires publics ou privés. 


\title{
Illegal gold miners in French Guiana: a neglected population with poor health
}

Maylis Douine ${ }^{1,2^{*}}$ (D) Emilie Mosnier ${ }^{2,3}$, Quentin Le Hingrat ${ }^{4}$, Charlotte Charpentier ${ }^{4}$, Florine Corlin ${ }^{1}$, Louise Hureau ${ }^{1}$, Antoine Adenis ${ }^{1,2}$, Yassamine Lazrek $^{5}$, Florence Niemetsky ${ }^{3}$, Anne-Laure Aucouturier ${ }^{1,3}$, Magalie Demar ${ }^{6}$, Lise Musset ${ }^{5}$ and Mathieu Nacher ${ }^{1,2}$

\begin{abstract}
Background: In French Guiana, a French overseas territory in South America, 6 to 10 thousands undocumented persons work illegally in gold mining sites in the Amazonian forest. Precarious life conditions lead to poor health but few data exist on the health status of illegal gold miners in French Guiana. The objective of this article was to describe the sociodemographic and health status of this vulnerable population.

Method: A prospective cross-sectional survey was conducted in 2015 on gold mine supply sites at the border between French Guiana and Suriname. Health status was assessed through medical examination, past medical history, haemoglobin concentration, and HIV and malaria testing. A questionnaire was used to collect data about the migration itinerary and life conditions on mining sites.

Results: Among the 421 adults included in the study, 93.8\% (395/421) were Brazilian, mainly from Maranhão (55.7\%, 220/395), the poorest Brazilian state. The sex ratio was 2.4. Overall, $48 \%$ of persons never went to school or beyond the primary level. The median time spent in gold mining was quite long (10 years), with a high turn-over. One third of the surveyed population $(37.1 \%, 156 / 421)$ had high blood pressure, and only two had a medical follow-up. Most persons had experienced malaria $(89.3 \%, 376 / 421)$. They declared frequent arboviroses and digestive disorders. Active leishmaniasis was observed in 8.3\% of gold miners. Among women, 28.5\% were anemic. Concerning HIV, 36.6\% (154/ 421) of persons, mainly men, never got tested before and 6 were tested positive, which represented an HIV prevalence of $1.43 \%(95 \% \mathrm{Cl}=0.29-2.5)$.

Conclusion: These findings support the hypothesis that mining in remote areas is linked to several specific illnesses. Theoretically, gold miners would be presumed to start their economical migration to French Guiana as a healthy group. However, their strenuous working and living conditions there lead to poor health caused by infectious and non infectious diseases. This description of their health status is precious for health policy planners in French Guiana given the importance of controlling communicable disease, and the severity and range of specific illnesses acquired by this neglected population.
\end{abstract}

Trial registration: Clinical trial registration PRS N NCT02903706.

Retrospectively registered 09/13/2016.

Keywords: Gold mining, French Guiana, Neglected population, Global health, Transborder, Hypertension, HIV, Malaria

\footnotetext{
* Correspondence: mdouine@yahoo.fr

${ }^{1}$ Centre d'Investigation Clinique Antilles-Guyane (Inserm 1424), Cayenne

Hospital, Av des Flamboyant, BP 6006, 97306 cedex Cayenne, French Guiana,

France

${ }^{2}$ Epidemiology of Tropical Parasitoses, EA 3593, Université de Guyane,

Cayenne, French Guiana, France

Full list of author information is available at the end of the article
}

(c) The Author(s). 2017 Open Access This article is distributed under the terms of the Creative Commons Attribution 4.0 International License (http://creativecommons.org/licenses/by/4.0/, which permits unrestricted use, distribution, and reproduction in any medium, provided you give appropriate credit to the original author(s) and the source, provide a link to the Creative Commons license, and indicate if changes were made. The Creative Commons Public Domain Dedication waiver (http://creativecommons.org/publicdomain/zero/1.0/) applies to the data made available in this article, unless otherwise stated. 


\section{Background}

French Guiana (FG) is a French overseas territory located in South America between Suriname and North of Brazil. Although the gross domestic product (GDP) is half that in mainland France (Insee), FG has a higher living standard than neighboring countries. The population of 250,000 inhabitants is composed of Creoles, Maroons, Amerindians, "metropolitan" from mainland France, and immigrants mainly from Caribbean and South America. Most live on the coastal area of this vast territory covered at $90 \%$ by Amazonian forest. About $20 \%$ of the population lives along the rivers inside the territory. Economical activity is lead by the European Space Center based in Kourou, then fishing, forest exploitation and gold mining activity. The gold richness of the soil was discovered in the middle of the nineteenth century [1]. Initially, exploitation was non industrial and varied according to gold prices. The soaring gold prices in the 1980's and the development of new technologies were followed in the 1990's by a boom of gold mining activity [2]. Alongside the legal activity, illegal gold mining increased drastically, attracting poor workers from neighboring countries. It is estimated that each year 10 tons of gold were extracted illegally while only 1 to 2 tons were extracted legally [3]. It is also estimated that there are about 6 to 10,000 illegal miners working in approximately 600 gold mining sites in the French Amazonian forest [4]. The two gold extraction types, alluvionnary or wells, are destructive for the environment with deforestation, mercury (used for gold particles recovery) pollution and river contamination $[1,5]$. Local populations pay a heavy toll, especially Amerindians [6, 7]. A military response was implemented in 2002 with the "Anaconda" operations then "Harpie" operation in 2008 aiming to destroy the logistical chain and supplies $[8,9]$. But the borders, represented by rivers and the vast Amazonian forest do not facilitate illegal gold mining control in FG. Illegal gold miners, also called "garimpeiros", are mainly Brazilian [10]. They live deep in the Amazonian forest, with exhausting work and poor hygiene conditions [11]. Access to emergency care is free in French Guiana, in the three hospitals in the main coastal cities as well as in health centers spread along the rivers where the population lives. But the remoteness of the mining sites, the boat costs and the fear of law enforcement hamper effective accessto care. Several outbreaks have been documented in this specific population in French Guiana: influenza A, shigellosis, beriberi, with a high morbimortality rate reflecting the poor health of this population $[11,12]$. Malaria also mainly affects gold miners in French Guiana, as in others countries of the Region [13-16]. Throughout the world, many studies have shown the impact of gold mining activities on health [17-21] but to date, there is no exploratory study on global health status of this specific population in FG.

A study was set up in 2015 to assess the malaria epidemiology in illegal gold miners working in French Guiana [10]. Living far from the health care system in the Amazonian forest, this precarious population is not easy to access because of logistical, administrative and security issues. Capitalizing on human resources and funding for the malaria study, further secondary objectives were added in order to assess the global health of this neglected population.

The aim of this paper was to describe the population of illegal gold miners working in French Guiana, their way of life, and identify challenges to their health care.

\section{Methods}

Study design

The study was cross-sectional, multicentric and observational. It was conducted between January and June 2015 at resting sites along the Suriname-French Guiana border.

\section{Settings}

Because of logistical limitations, legal issues and security concerns, recruitment was made at "resting sites" which are spread along the borders. These sites are structured as wooden shacks that are built around bars or shops. Garimpeiros use these places to rest and to fulfill their needs for supplies, medical care or leisure.

\section{Study size}

Designed for malaria assessment, the needed sample size was 387 for an expected Plasmodium prevalence of 50\%.

\section{Participants}

The inclusion criteria were being over 18 years of age, working in illegal gold mining in FG, being at the resting site for less than 7 days, and accepting to participate in the study. Recruitment was made using the snow-ball effect [22]. After recording the informed consent, a blood sample was taken for malaria diagnosis, haemoglobin measure and an HIV test.

\section{Variables}

A structured questionnaire was administered by a nurse with an interpreter to collect sociodemographic data, and data concerning the way of life on the mining site, movements, health problems and medical history. Medical examination recorded blood pressure (after a minimum of 15 min of rest and lying down), heart auscultation, presence of diarrhea, splenomegaly, oedema and active leishmaniasis lesions. Hemoglobin was measured with the HemoCue ${ }^{\circledast}$ system which was calibrated 
every week. According to the World Health Organization (WHO), anemia was defined as haemoglobin below $130 \mathrm{~g} / \mathrm{l}$ for men, below $120 \mathrm{~g} / \mathrm{l}$ for women and below $110 \mathrm{~g} / \mathrm{l}$ for pregnant women [23]. Blood pressure (BP) was measured twice with a wrist monitor after resting. It was classified according to European recommendations [24]: normal (systolic BP (SBP) $<140 \mathrm{mmHg}$, diastolic BP (DBP) $<90 \mathrm{mmHg}$ ), grade 1 $(140<\mathrm{SBP}<160,90<\mathrm{DBP}<100)$, grade 2 $(160<\mathrm{SBP}<180,100<\mathrm{DBP}<110)$, and grade 3 $(180<$ SBP, $110<$ DBP). Diarrhea was defined as currently passing three or more stools per day. Two dry blood spots (DBS) on filter paper were sent to the virology department of Bichat Hospital in Paris, France, for HIV testing. After DBS elution, HIV serodiagnosis was performed with a 4th generation ELISA assay (Architect HIV Ag/Ac Combo, Abbott Diagnostics, IL, USA). Positive samples were confirmed with an HIV-1 Western Blot assay (New LAV Blot 1, Biorad, Marnes-laCoquette, France). We performed Immunocomb II HIV1/ 2 BiSpot test (Alere, Jouy-en-Josas, France) to discriminate between HIV-1 and HIV-2. An appointment at a French health center was given to all participants to get the results, as well as a mosquito-net and condoms.

\section{Statistical methods}

Descriptive data analyses were carried out using Stata12 software (College Station, Texas, USA). Bivariate analysis used the Chi-Squaretest, t-Student or Kruskall-Wallis tests depending on the type of variable. All statistical analyses used a 5\% significance level. Data were mapped with QGIS software. GDP data come from the World Bank online.

\section{Ethical and regulatory approvals}

As the recruitment took place on the Surinamese border, a partnership with the National Malaria Program of Suriname was implemented and authorizations obtained. In France, the study was approved by the Comitéd' Evaluation Ethique de l'Inserm, an Ethics Committee on Research: Process $n^{\circ}$ 14-187 (IRB00003888 FWA00005831). The authorization of importation of human biological samples was obtained from the French Ministry of Education and Research, Process $\mathrm{N}^{\circ}$ IE-2014-758. The database was anonymized and declared to the Commission Nationale Informatiqueet Libertés.

\section{Results}

Sociodemographic profile of illegal gold miners in French Guiana

During the study, 421 persons were included. The sex ratio was 2.4. Among the 124 women, seven were pregnant $(5.6 \%)$. The median age was 37 years [interquartile range $(\mathrm{IQR})=30-45]$, without difference between sexes.
Most of them were born in Brazil $(93.8 \%, 395 / 421)$. Other persons were born in Suriname $(3.6 \%, 15 / 421)$, in France $(1.7 \%, 7 / 421)$, in Guyana $(0.5 \%, 2 / 421)$, in Venezuela $(0.2 \%, 1 / 421)$ and in Peru $(0.2 \%, 1 / 421)$. In Brazil, states of birth were mainly Maranhão (55.7\%, 220/395), Para (23.8\%, 94/395) and Amapa (6.1\%, 24/ 395) (Fig. 1). Almost all (99\%) spoke Portuguese, 96.9\% fluently (408/421) and 2.1\% (9/421) a little. Only 9\% (38/421) spoke French, fluently or a little. Other languages were Sranan-tongo (Maroons language) (18.8\%), English (8.0\%), Spanish (7.1\%) and Dutch (6.9\%).

Half of illegal gold miners (48\%) never went to school or only had a primary school level. Women had significantly higher education than men: $72.6 \%$ had a secondary school level versus $43.4 \%$ of men $(p<0.001)$. Only 13 workers (3.1\%) had French social security, one of which was born in France, 3 in Suriname, 9 in Brazil; 7 were women, and 2 were pregnant.

\section{Gold mining activity}

Garimpeiros had been working for a median 10 years in gold mining [IQR $=5-15]$, with a minimum of 2 weeks and a maximum of 40 years. This differed between sexes: median duration was 7 years for women versus 10 years for men $(p<0.001)$. The surveyed persons currently worked in 68 different mining sites, which were grouped in 10 zones according to their proximity and river basin. There was no difference of sex ratio or duration of gold mining activity between those zones, but people were younger in Sophia, Papaïchton and Beiman areas than in others mining areas $(p=0.002)$. Place of birth (country and state in Brazil) also differed between zones $(p<0.001)$. Twenty-seven persons were included directly on mining sites in French Guiana. For people included at resting sites, the distance between the resting site and the mining site was one day or more for $63.7 \%$ (251/ 394). Modes of transport were boat (99.5\%), foot (37.8\%), quad (12.8\%) and car (1.7\%). During the last three years, gold miners had worked in a median number of three different mining sites [IQR $=2-4]$, ranging from 1 to 25 sites. The majority worked only in FG $(67.5 \%, 284 / 421)$. Other persons worked also in Suriname (29.2\%), in Brazil (3.6\%), in Guyana (2.8\%) or in Venezuela (1.2\%). Fifteen (3.6\%) worked in three or more countries. They had been on the current mining site for a median of six months [IQR $=3-18$ months]. The gold extraction was alluvial for $48.5 \%(204 / 421)$ of gold miners, wells for $8.1 \%$ (34/421) and both for $39.2 \%$ (165/421). Other extraction modes were "moinho" (rock crushing) (9/421) or "pioupiou" (metal detector) (3/421). Six did not answer this question.

Type of work in mining sites differed statistically by sex and 25 persons declared having two jobs. Women were mainly cookers or housewifes $(53.2 \%)$ or travelling 


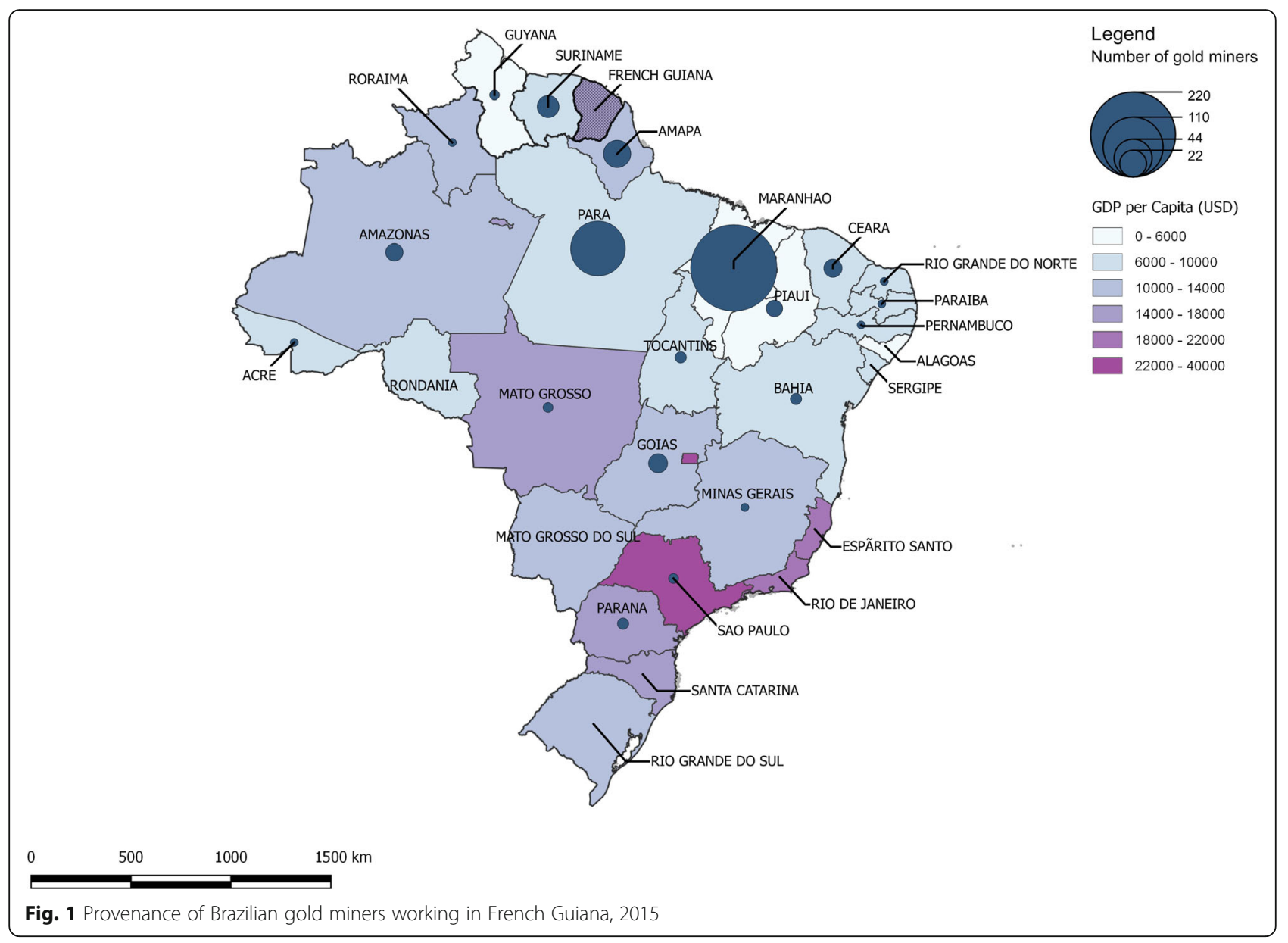

sellers (40.3\%); 9.3\% declared sex work activity. Among men, 68\% were gold miners, $12.1 \%$ travelling sellers, 7.7\% transporters, $5.7 \%$ machine operators (Fig. 2). Most of them (78.8\%) worked only during day-time but $21.2 \%$ declared working day and night.

During the last six months, interviewed persons reported having left the mining site a median number of two times [IQR $=1-4$ ] mainly for supplies $(44.4 \%)$, rest (37\%), medical care $(25.6 \%)$ or family visit (16.4\%).

During the past year, $68.2 \%(287 / 421)$ of people declared having moved in a city of the Guiana Shield, a median number of three times [IQR $=1-6]$. Most of them went to Paramaribo (49.4\%), then Saint Laurent du Maroni (20.1\%), Belem (19\%), Oiapoque (13\%), Macapa (9.5\%), Cayenne (8\%) and Kourou (2.6\%) (Fig. 3). A quarter of Brazilian persons had been to Brazil during the past year $(100 / 395,25.3 \%)$.

\section{Health status of illegal gold miners}

When questioned about the three main problems occurring at the mining site, 357 persons cited malaria, then leishmaniasis (203), dengue or chikungunya (135), digestive disorders (76), and musculoskeletal disorders (67) (Fig. 4).

More than a third $(37.1 \%, 95 \% \mathrm{CI}=32.4-41.7)$ of gold miners suffered from high blood pressure (HBP), mainly men (42.1\% versus 25\%, $p=0.001)$ : $93(22.1 \%)$ at grade $1,47(11.2 \%)$ at grade 2 , and $16(3.8 \%)$ at grade 3. Among the ten persons reporting a past history of HBP, two had a medical follow up at the health center of Maripasoula and 2 had erratic treatment use. Concerning cardiac disorders, 7 (1.7\%) persons declared having had a myocardial infarction and 14 (3.3\%) suffering from cardiac rhythm disorder. Cardiac auscultation found two heart murmurs and four rhythm disorders but not in any of the gold miners with cardiac past history. Two had edema of the lower limbs.

Twenty two percent of included persons had anemia (95\%CI $=18-25.9)$, mainly women $(28.5 \%$ versus $19.3 \%$, $p=0.038)$, none with hemoglobin below $8 \mathrm{~g} / \mathrm{dl}$. Anemia was not related with pregnancy among women. Twenty three persons declared currently having diarrhea (5.5\%, 23/421). Thirty five persons $(8.3 \%)$ had active leishmaniasis. Most of them $(65.7 \%, 23 / 35)$ had only one lesion, but twelve (34.3\%) had several lesions, up to 5 . During 

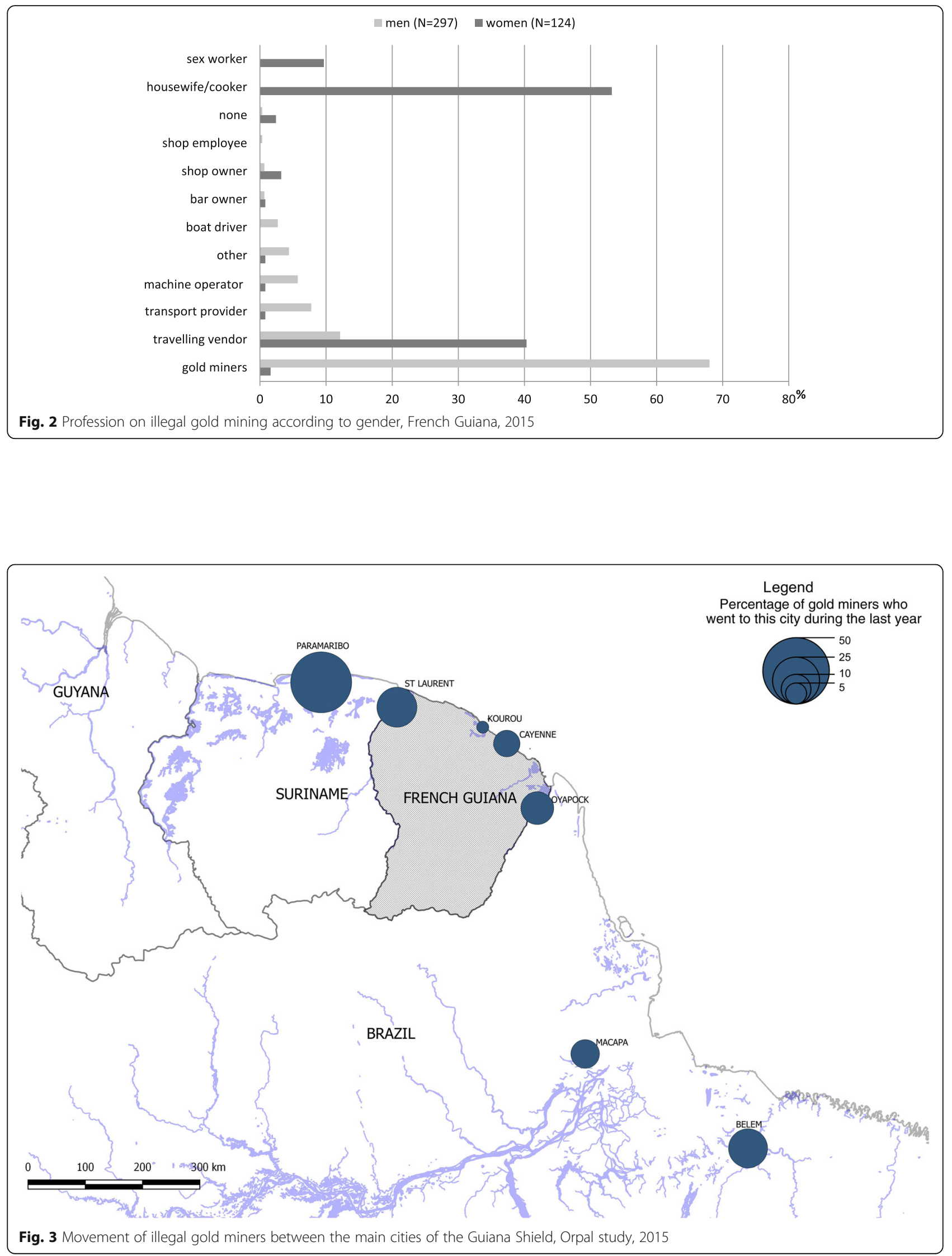


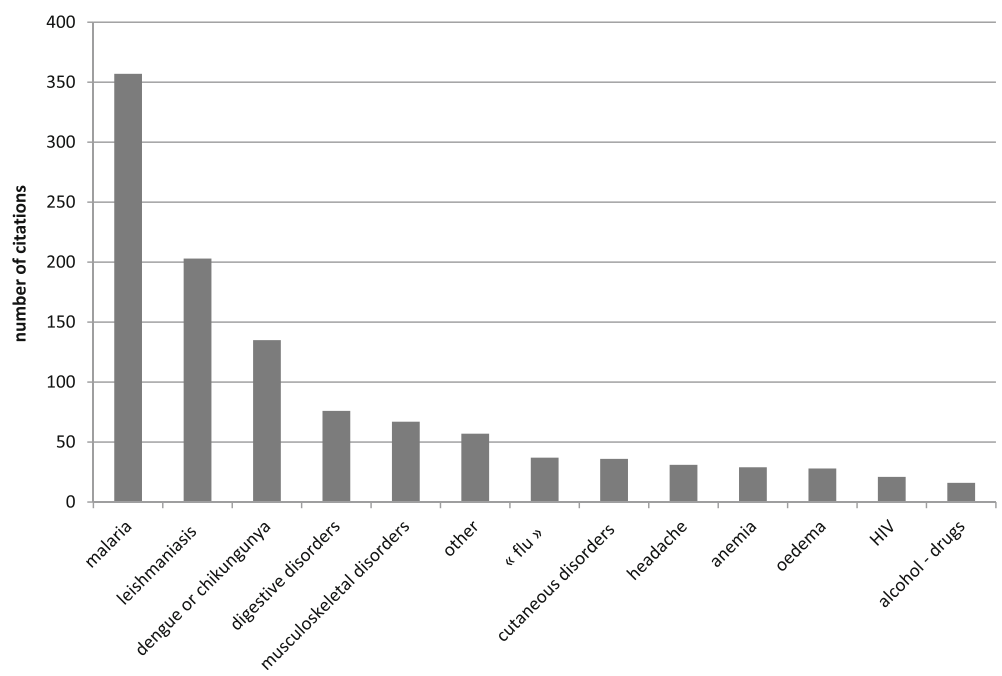

Fig. 4 Main health problem occurring on mining site according to gold miners, French Guiana, 2015

the past year, 57 persons (13.5\%) declared having had an anti-leishmanial treatment. Among them, 18 (31.6\%) still had active leishmaniasis at inclusion time. Almost all (89.3\%) declared a past malaria history, of which $66.2 \%$ declared more than 7 prior malaria attacks. Plasmodium spp. prevalence was very high, $22.3 \%(\mathrm{CI} 95 \%=18.3-$ 26.3) of the study population [10]. Five persons (1.2\%) had a splenomegaly, among which 3 had a PCR-Plasmodium spp. positive. Concerning HIV, 36.6\% (154/421) had never been tested for HIV. This proportion differed between sexes: $17.7 \%$ of women versus $44.4 \%$ of men $(p<0.001)$. Six samples were found positive with the ELISA assay which is a prevalence of $1.43 \%$ (95\%CI $=0.29-2.56)$. They all presented Western blot profiles of chronic HIV infection and were positive only for HIV-1 with Immunocomb ${ }^{\circ}$. One was already known to be HIV positive and received care atthe health center of Maripasoula. The 6 HIV positive individuals were aged between 29 to 47 years with a sex ratio of 2:1. The two women declared to be a housewife and cooks, and did not mention sex work. The men were: a shop employee [1], a travelling vendor [1] and gold miners [2]. Only three of the people tested positive retrieved their results.

\section{Discussion}

\section{Illegal gold miners: mainly poor Brazilian people}

Illegal gold miners working in FG were mainly Brazilian, from the poorest states of Brazil, although without direct borders with FG. Actually Maranhão and Para have the highest poverty and unemployment rates in Brazil (Instituto Brasileiro de Geografia e Estatística). Often illiterate, the motive of migration of these persons for gold mining is thus mainly economic as shown in other qualitative reports among miners [25-28]. The provenance of gold miners statistically differed between the different mining zones, suggesting that recruitment could be favored by entourage or people who already experimented gold mining around them [25]. The "forest language" was thus Portuguese, with $99 \%$ of people speaking this language at least a little, as observed in Suriname [29]. As in others studies [29, 30], women represented one third of included persons. They had been working in gold mining areas for a shorter time than men, they had the same age but had higher educational level. They often worked in mining sites to support their family financially in Brazil $[25,28]$. Profession on the mining site were varied, from mining to support activities thus constituting a micro-society in the Amazonian rainforest as described in Suriname [29]. Sex work activity was probably under-declared due to the attached stigmatization; but it could also be that, contrary to the popular opinion, the majority of women did not engage in sex work on mining camps.

The majority of the surveyed population reported having only worked in French Guiana during the last three years. Actually, in Brazil, illegal gold mining is severely repressed and in Suriname, corruption and concurrence with local persons make it difficult to work for one's own account $[9,25]$. Since 2010, more and more wells are being used to extract secondary gold because they are more productive and more difficult to locate by helicopter [9]. Work conditions are known harsh in both: mud and sun in alluvionnary, groundfalls and stuffiness in wells [17]. A fifth of garimpeiros worked day and night, testifying of their exhausting work.

\section{Health problems on mining sites}

Malaria was the first health problem cited by interviewed people. Although it might have been influenced by the main topic of the study, almost all declared past 
malaria history and Plasmodium spp. prevalence was very high $[10,30]$. More surprisingly, arboviroses, dengue and chikungunya, were mentioned in second although Aedes aegypti, the main vector in French Guiana, usually lays in clean still water in urban areas.In fact, $A$. aegypti larvae were found in Bromeliad plants in the rainforest, suggesting that those viral outbreaks can emerge at mining sites [31]. In Australia, in a very different ecological context, gold miners also suffered from dengue and $A$. aegypti larvae were found in flooded disused mine shafts and wells [17,32]. Other explanation is the presence of other arbovirus, as Mayaro virus, responsible for sporadic infections or small outbreak in the Amazon region, usually limited to forest areas because of the presence of the vector [33-35]. Mayaro virus infections are probably under-diagnosed because of confusion with other mosquito-borne virus infections, especially dengue fever which is endemic to the same areas [35]. The recent emergence of zika and chikungunya virus had further added to this confusion, especially because of extended arthralgia reported with both infections (chikungunya and Mayaro virus).

Digestive disorders also appeared as an important health problem, linked to the lack of latrines and drinking water [25]. High prevalence of hookworm disease was also previously described on this area [11,36,37]. This reflects the multifactorial dynamics of waterborne disease in tropical area, including human behavior (water consumption, occupational activity) and malnutrition in precarious conditions of this exposed population [38].

Prevalence of anemia among women in this study was higher than reported by WHO among women of reproductive age in the Americas: $28.5 \%(95 \% \mathrm{CI}=20.4-36.5)$ versus $16.8 \%$ (95\% $\mathrm{CI}=12.6-23.8$ ) [39]. This can be due to multifactorial causes such as recurrent malaria, poor intestinal absorption related to parasitic diseases, blood loss due to hookworm infection and/or poor food with vitamins and nutrients deficiency. Indeed, a large outbreak of thiamine deficiency among this population was described in 2013-2014 [38].

The prevalence of HBP was higher in this study than in Brazil(37.1\% versus $22.8 \%$ ) [40], while this specific population is young, active and with normal weight. Chronic intoxication to heavy metals such as lead and/or mercury could be an explanation even if the link with HBP is not perfectly established [41-43]. Exposure to lead might be due to cassava consumption as suspected in Amerindian population who has an extremely high level of lead poisoning [44]. Chagas disease, endemic in Latin America particularly in rural area, was also previously described as a risk factor for high blood pressure [45]. Up to 30\% of chronically infected people develop cardiac alteration [46].

Illegal gold miners are also exposed to cutaneous disorders such as leishmaniasis due to L.guyanensis or
L.brasiliensis [47]. Transmitted by sandflies, the reservoir in FG is the two-toed sloth mostly present in the rainforest canopy [48]. Thus deforestation increases contacts with this pathogen. As for malaria [49], the high level of self-medication threatens with the risk of emergence of antileismanial resistance.

Gold mines are potential hotspots for HIV transmission. Sex work seems to be very frequent in gold mining and HIV prevalence has been shown to be higher in sex worker populations [50-53]. Given the large confidence interval of HIV prevalence, the estimate should be interpreted with caution because the study was not designed to evaluate this. Although it seems higher than in mainland France (HIV prevalence $=0.2 \%[54]$ ) or in Brazil (HIV prevalence $=0.39 \%$, [55]), it is close to estimates in FG (1\% in pregnant women [56]). In Brazil, while the HIV epidemic is stabilized in southern regions, HIV detection increased by $62.6 \%$ in the past decade in the northeastern region, where most of gold miners are from [57]. There is no prevention for HIV among illegal gold miners and condoms are very expensive on mining sites, reaching up to 10 euros per condom. Women had higher HIV-testing status than men probably because of routine testing during pregnancy. Among the seven pregnant women, all declared having already been tested and were negative for HIV. In this mobile population, only half of HIV positive persons went to get their results at the health center. These findings show low HIV-testing rates, particularly in men and strongly underline the need to focus efforts on rapid testing rather than serology in this setting to ensure that they have their results.

\section{Other potential pathologies described in literature}

Leprosy cases diagnosed in FG mainly concern gold miners originating from Brazil, the country with the second highest number of leprosy cases in the world $[58,59]$. Bat bites occurred frequently on mining sites, with a potential risk of rabies outbreaks $[17,25,26]$. Trauma were frequent and sometimes severe, motivating $41 \%$ of emergency phone calls, mainly due to falling tree, quad accident, or weapon wounds [26]. Garimpeiros are also exposed to fauna poisoning (snake, scorpion...). Given the hard life conditions, alcohol and drugs are often used on gold mining sites [26]. The use of mercury despite it being outlawed exposed gold miners to acute and chronic disorders (neurological respiratory and digestive disorders) $[17,18,60]$. Sexually transmitted diseases and respiratory infections as tuberculosis also seem to be more frequent $[17,61]$.

\section{Migration route and health care}

Migration could hamper access to health care because of the poverty related to their status, the lack of knowledge about health care or geographical isolation. In a recent 
study, Médecins Sans Frontières (Doctors Without Borders) reported that death and default rates of tuberculosis treatment for migrant workers were higher than the rates for refugees [62]. This study also underlines the findings of other studies done in areas where migration issues impact malaria control [63]. However, our results suggest that there is a regular and frequent border crossing by gold miners to go to resting sites (median of 2 times per 6 months). Although gold miners are a mobile population who frequently change mining areas, the resting sites might be potentially strategic stability sites of medical mediation. An empirical transnational global health framework taking into account gold miners' particularities thus leads to innovative participatory public health models. The boundaries between countries, isolation and migration flows challenge traditional health systems and promote innovative strategies of medical care.

\section{Public health consequences}

These findings support that mining in remote area is strongly related to several specific illness. Theoretically, given the strenuous working conditions, gold miners would be presumed to start their economical migration to French Guiana as a healthy group, which is called the "salmon bias" $[64,65]$. However, their living conditions there might lead to poor health caused by infectious and non infectious diseases. Their close contact with the fauna creates good conditions for the emergence of new pathogens or the reemergence of zoonoses like rabies, yellow fever and other arboviroses [66]. International migration of gold miners also causes social disruptions, including residential and conjugal instability, that may generate risky behaviors, in particular for sexually transmitted disease [67].

Other studies in French Guiana, as elsewhere in the world, suggest that undocumented immigrants are most vulnerable with regards to health $[68,69]$. Even if emergency care is theoretically free of charge, access to care is not effective for illegal gold miners because of the remoteness of the mines and the fear of law enforcement [49]. Self-medication is thus very common. Many drugs circulate on the black market and the high price pushes miners to reduce the dosage, threatening with the emergence of resistance to antibiotics and antiparasitic drugs $[10,26,30]$. Moving all around the Guiana Shield and Brazil, gold miners could disseminate other pathogens on their way, as already shown with malaria [70]. The transborder context complexifies care for this neglected population with political, economical and demographical issues. Prevention measures such as mosquito nets, condoms or drinking boiled water often seem not to be used and could be promoted [26, 29].

\section{Conclusion}

The hostile living conditions at mining sites erodes the miners' health and leads to a broad range of serious non communicable and communicable diseases that may spread beyond mining sites and beyond borders. Improving the knowledge on their specific burden of disease is crucial for health policy planners for disease control. An effective response will benefit from multisectoral approaches for dealing with specific diseaserelated risks, behaviors and environmental Amazonian factors. Consequences of inaction could have repercussion far beyond French Guiana.

\section{Abbreviations \\ AIDS: acquired immune deficiency syndrome; Cl: confidence interval; DBP: diastolic blood pressure; FG: French Guiana; GDP: gross domestic product; HBP: high blood pressure; HIV: human immunodeficiency virus; IQR: interquartile range; SBP: systolic blood pressure}

Acknowledgements

Authors thanks Mr. Guillaume Noël for help with the mapping.

Funding

This study was funded by European Funds for Regional Development (Feder), $N^{\circ}$ Presage 32,078 . The Funding body had no role in the study and in the publication process.

Availability of data and materials

Data can be requested from the corresponding author.

\section{Authors' contributions}

$M D o, M N, A A$ and $L M$ designed the study. FC, LH, MD made acquisition of the data. $\mathrm{QH}, \mathrm{CC}, \mathrm{LM}$ and $\mathrm{MDe}$ performed biological exams. MDo and MN analyzed the data. MD, MN, $\mathrm{QH}, \mathrm{CC}, \mathrm{LM}, \mathrm{MDe}$ and $\mathrm{EM}$ wrote the first draft of the manuscript. All authors contributed to subsequent draft and have reviewed and agreed with the content of the final manuscript. All authors read and approved the final manuscript.

\section{Authors' information}

Dr. Maylis Douine is a medical doctor with an PHD degree at the Clinical Investigation Center in Cayenne. She is working mainly on epidemiological studies assessing infectious diseases as malaria, chikungunya, Buruli ulcer and papillomavirus.

\section{Ethics approval and consent to participate}

The study was approved by the Comitéd'Evaluation Ethique de l'Inserm, an Ethics Committee on Research: Process n¹4-187 (IRB00003888 FWA00005831). All participants gave their written consent.

\section{Consent for publication}

Not applicable.

\section{Competing interests}

The authors declare that they have not conflict of interest.

\section{Publisher's Note}

Springer Nature remains neutral with regard to jurisdictional claims in published maps and institutional affiliations.

\section{Author details}

${ }^{1}$ Centre d'Investigation Clinique Antilles-Guyane (Inserm 1424), Cayenne Hospital, Av des Flamboyant, BP 6006, 97306 cedex Cayenne, French Guiana, France. ${ }^{2}$ Epidemiology of Tropical Parasitoses, EA 3593, Université de Guyane, Cayenne, French Guiana, France. ${ }^{3}$ Centres Délocalisés de Prévention et de Soins, Cayenne Hospital, Cayenne, French Guiana, France. ${ }^{4}$ INSERM UMR1137, IAME Université Paris Diderot Sorbonne Paris Cité, AP-HP, Laboratoire de Virologie, Hôpital Bichat-Claude Bernard, Paris, France. ${ }^{5}$ Laboratoire de 
parasitologie, WHO Collaborating Center for Surveillance of Anti-Malarial Drug Resistance, Centre National de Référence du paludisme, Institut Pasteur de la Guyane, Cayenne, French Guiana, France. ${ }^{6}$ Academic Laboratory of Parasitology - Mycology, Cayenne Hospital, Cayenne, French Guiana, France.

Received: 19 January 2017 Accepted: 30 June 2017

Published online: 17 July 2017

\section{References}

1. Moullet D, Saffache P, Transler A-L. L'orpaillage en Guyane française : synthèse des connaissances. Études Caribéennes [Internet]. 2006 [cited 2016 Jul 19];(4). Availablefrom: http://etudescaribeennes.revues.org/753. Accessed 19 Jul 2016.

2. Petot J. Histoire contemporaine de l'or de Guyane. Paris: L'Harmattan; 1992.

3. World Wild Fund France. Lutte contre l'orpaillage illégal en Guyane: des pistes scientifiques pour tracer les grains d'or [Internet]. 2016. Available from: http://www.wwf.fr/?7202/Lutte-contre-l-orpaillage-illegal-en-Guyanedes-pistes-scientifiques-pour-tracer-les-grains-d-or. Accessed 4 Jan 2017.

4. World Wild Fund. Dossier de presse : L'orpaillage illégal en Guyane : Fléau majeur pour la forêt, l'eau et la santé humaine [Internet]. 2008. Available from: https://documentation.outre-mer.gouv.fr/Record.htm?idlist=1\&record= 19101265124919294479. Accessed 19 Jul 2016.

5. Hammond DS, Gond V, de Thoisy B, Forget P-M, DeDijn BPE. Causes and consequences of a tropical forest gold rush in the Guiana shield. South America Ambio. 2007 Dec;36(8):661-70.

6. Cire Antilles-Guyane. Le mercure en Guyane. Risques sanitaires et enjeux de santé publique. Numéro thématique. 2007. Available from: http://opac.invs. sante.fr/index.php?|vl=notice_display\&id=3855. Accessed 19 Jul 2016.

7. Boudou A, Dominique Y, Cordier S, Frery N. Les chercheurs d'or et la pollution par le mercure en Guyane française : conséquences environnementales et sanitaires. Environ Risques Santé. 2006;5(3):167-79.

8. Préfecture de la Guyane. Lutte contre l'orpaillage illégal en Guyane. [Internet]. 2014. Availablefrom: http://www.guyane.pref.gouv.fr/Publications/ Etudes-sur-la-Guyane/Lutte-contre-I-orpaillage-illegale-Bilan-et-actions/ \%28language\%29/fre-FR. Accessed 1 Apr 2016.

9. Auriel P. La lutte contre l'orpaillage illégal aux frontières de la Guyane [Internet]. Institut des Hautes Etudes Internationales; 2013. Availablefrom: http://www.ihei.fr/wp-content/uploads/2011/10/M\%C3\%A9moire-P.-AurielCEJI-2012-2013.pdf. Accessed 10 Nov 2016.

10. Douine M, Musset L, Corlin F, Pelleau S, Pasquier J, Mutricy L, et al. Prevalence of plasmodium spp. in illegal gold miners in French Guiana in 2015: a hidden but critical malaria reservoir. Malar J. 2016;15:315.

11. Mosnier E, Carvalho L, Mahamat A, Chappert J, Ledrans M, Ville M, et al. Épidémies multiples dans des camps d'orpaillage en forêt amazonienne (Guyane française) en 2013 : quelles leçons pour l'accès aux soins et à la prévention? Bulletin Epidemiologique Hebdomadaire. 2015;1 1(12):181-9.

12. Niemetzky F, Mosnier E, Nacher M, Stroot J, Brousse P, Pommier de Santi V. Epidémie de Béri-Béri chez des orpailleurs en Guyane française. Bull Veille Sanit - Cire Antill-Guyane. 2015;8(9):6.

13. De Andrade AL, Martelli CM, Oliveira RM, Arias JR, Zicker F, Pang L. High prevalence of asymptomatic malaria in gold mining areas in Brazil. Clin Infect Dis. 1995;20(2):475

14. Moreno JE, Rubio-Palis Y, PáEz E, PéRez E, Sánchez V. Abundance, biting behaviour and parous rate of anopheline mosquito species in relation to malaria incidence in gold-mining areas of southern Venezuela. Med VetEntomol. 2007;21 (4):339-49.

15. Castellanos A, Chaparro-Narváez P, Morales-Plaza CD, Alzate A, Padilla J, Arévalo M, et al. Malaria in gold-mining areas in Colombia. Mem Inst Oswaldo Cruz 2016;111(1):59-66.

16. Pommier de Santi V, Dia A, Adde A, Hyvert G, Galant J, Mazevet M, et al. Malaria in French Guiana linked to illegal gold mining. Emerg Infect Dis. 2016; 22(2):344-6.

17. Eisler R. Health risks of gold miners: a synoptic review. Environ Geochem Health. 2003:25(3):325-45.

18. Taubira C. L'or en Guyane. Eclats et Artifices. Rapport remis au Premier Ministre. La documentation Française; 2000. 155. http://www. ladocumentationfrancaise.fr/rapports-publics/004001895/index.shtml.

19. de Souza ES, Texeira RA, da Costa HSC, Oliveira FJ, Melo LCA, do Carmo Freitas Faial K, et al. Assessment of risk to human health from simultaneous exposure to multiple contaminants in an artisanal gold mine in Serra Pelada, Pará, Brazil. Sci Total Environ. 2017;576:683-95.
20. Salas ML, Quezada S, Basagoitia A, Fernandez T, Herrera R, Parra M, et al. Working conditions, workplace violence, and psychological distress in Andean miners: a cross-sectional study across three countries. Ann Glob Health. 2015;81(4):465-74.

21. Kyeremateng-Amoah E, Clarke E. Injuries among artisanal and small-scale gold miners in Ghana. Int J Environ Res Public Health. 2015;12(9):10886-96.

22. Sadler GR, Lee H-C, Lim RS-H, Fullerton J. Research article: recruitment of hardto-reach population subgroups via adaptations of the snowball sampling strategy: hard-to-reach populations. Nurs Health Sci. 2010;12(3):369-74.

23. World Health Organization. Haemoglobin concentrations for the diagnosis of anaemia and assessment of severity [Internet]. World Health Organization; 2011. Available from: http://www.who.int/vmnis/indicators/ haemoglobin.pdf?ua=1. Accessed 8 Nov 2016.

24. Mancia G, De Backer G, Dominiczak A, Cifkova R, Fagard R, Germano G, et al. 2007 guidelines for the Management of Arterial Hypertension: the task force for the Management of Arterial Hypertension of the European Society of Hypertension (ESH) and of the European Society of Cardiology (ESC). J Hypertens. 2007 Jun;25(6):1105-87.

25. Le Tourneau FM. Les orpailleurs clandestins de Guyane française. Premier rapport d'étape dans l'étude FAG/CNRS. CNRS; 2016.

26. Egman G. Évaluation des recommandations pour l'amélioration de la prise en charge des urgences médicales sur les sites aurifères en Guyane française. France: Université de Nancy; 2011.

27. Tabor D. Like butterflies in the jungle. The quest for the new El Dorado. Harper's Magazine. 2011;45-54. https://harpers.org/archive/2011/02/likebutterflies-in-the-jungle/.

28. Douine M. Paludisme: I'autre fièvre de l'or. Une Saison En Guyane. 2015:76-83.

29. Heemskerk M, Duijves C. Study on the knowledge, attitudes and practices of malaria and malaria treatment in the small-scale gold mining sector in Suriname. [Internet]. Submitted to the US Agency for International Development by the Systems for Improved Access to Pharmaceuticals and Services (SIAPS) Program:; 2013. Available from: http://siapsprogram.org/publication/study-on-theknowledge-attitudes-and-practices-of-malaria-and-malaria-treatment-in-the-smallscale-gold-mining-sector-in-suriname/. Accessed 1 Apr 2016.

30. Pommier de Santi V, Djossou FCL, Barthes N, Bogreau HC, Hyvert G, Nguyen $C$, et al. Malaria Hyperendemicity and risk for Artemisinin resistance among illegal gold miners. French Guiana Emerg Infect Dis. 2016;22(5):903-6.

31. Fouque F, Garinci R, Gaborit P. Epidemiological and entomological surveillance of the co-circulation of DEN-1, DEN-2 and DEN-4 viruses in French Guiana. Trop Med Int Health TM IH. 2004;9(1):41-6.

32. Russell BM, Muir LE, Weinstein P, Kay BH. Surveillance of the mosquito Aedes aegypti and its biocontrol with the copepod Mesocyclops aspericornis in Australian wells and gold mines. Med Vet Entomol. 1996;10(2):155-60.

33. Causey OR, Maroja OM. Mayaro virus: a new human disease agent. III. Investigation of an epidemic of acute febrile illness on the river Guama in Pará, Brazil, and isolation of Mayaro virus as causative agent. Am J Trop Med Hyg. 1957;6(6):1017-23.

34. Pinheiro FP, Freitas RB, Travassos da Rosa JF, Gabbay YB, Mello WA, JW LD. An outbreak of Mayaro virus disease in Belterra, Brazil. I. Clinical and virological findings. Am J Trop Med Hyg. 1981;30(3):674-81.

35. Mutricy R, Epelboin L, Mosnier E, Matheus S, Djossou F, Rousset D. Caractéristiques clinico-biologiques d'une arbovirose méconnue en Guyane française : le virus mayaro. Med Mal Infect. 2016 Jun;46(4 Suppl 1):106.

36. Carme B. Les parasitoses humaines en Guyane française. Presse Medicale Paris Fr 1983. 2001;30(32):1601-8.

37. Carme B, Motard A, Bau P, Day C, Aznar C, Moreau B. Intestinal parasitoses among Wayampi Indians from French Guiana. Parasite Paris Fr. 2002 Jun;9(2):167-74.

38. Mosnier E, Niemetzky F, Stroot J, Pommier de Santi V, Brousse P, Garmit B, et al. A Large outbreak of thiamine deficiency among illegal gold miners in French Guiana. AJTMH [Internet]. 2017; Available from: http://www.ajtmh. org/content/journals/10.4269/ajtmh.15-0906. Accessed 4 Jan 2017.

39. World Health Organization. The global prevalence of anaemia in 2011 . [Internet]. World Health Organization; 2011. Available from: http://www.who. int/nutrition/publications/micronutrients/global_prevalence_anaemia_2011/ en/. Accessed 17 Nov 2016.

40. Malta DC, Santos NB dos, Perillo RD, Szwarcwald CL, Malta DC, Santos NB dos, et al. Prevalence of high blood pressure measured in the Brazilian population, National Health Survey, 2013. Sao Paulo Med J 2016;134(2):163-70.

41. Dórea JG, de Souza JR, Rodrigues P, Ferrari I, Barbosa AC. Hair mercury (signature of fish consumption) and cardiovascular risk in Munduruku and Kayabi Indians of Amazonia. Environ Res. 2005;97(2):209-19. 
42. Simões MR, Azevedo BF, Fiorim J, Jr Freire DD, Covre EP, Vassallo DV, et al. Chronic mercury exposure impairs the sympathovagal control of the rat heart. Clin Exp Pharmacol Physiol. 2016;43(11):1038-45.

43. Navas-Acien A, Guallar E, Silbergeld EK, Rothenberg SJ. Lead exposure and cardiovascular disease-a systematic review. Environ Health Perspect. 2007; 115(3):472-82.

44. Carneiro MFH, Evangelista FS, Barbosa F. Manioc flour consumption as a risk factor for lead poisoning in the Brazilian Amazon. J Toxicol Environ Health A. 2013;76(3):206-16.

45. Vicco MH, Rodeles L, Yódice A, Marcipar I. Chagas disease, a risk factor for high blood pressure. Blood Press. 2014;23(6):345-8.

46. World Health Organization. Chagas disease (American trypanosomiasis) [Internet]. WHO. [cited 2017 Jan 4]. Available from: http://www.who.int/ chagas/en/

47. Camara Coelho LI, Paes M, Guerra JA, Barbosa M Das G, Coelho C, Lima B, et al. Characterization of Leishmania spp. causing cutaneous leishmaniasis in Manaus, Amazonas, Brazil. Parasitol Res 2011;108(3):671-77.

48. Rotureau B, Couppié $P$, Nacher M, Dedet JP, Carme B. Cutaneous leishmaniases in French Guiana. Bull Soc Pathol Exot 1990. 2007;100(4):251-60.

49. Douine M, Musset L, Corlin F, Pelleau S, Mutricy L, Adenis A, et al. Paludisme et orpaillage illégal en Guyane: un enjeu majeur de santé publique [Malaria and illegal gold mining in French Guiana: a major public health challenge]. Bull Epidémiologique Hebd - BEH. 2017 in press;

50. Nacher M, Vantilcke V, Parriault MC, Van Melle A, Hanf M, Labadie G, et al. What is driving the HIV epidemic in French Guiana? Int J STD AIDS. 2010; 21(5):359-61.

51. Bourdier F. L'avancée du sida dans les zones frontalières guyano-brésiliennes. Hommes \& Migrations. 1256th ed. 2005;116-29.

52. Parriault M-C, van Melle A, Basurko C, Gaubert-Marechal E, Macena RHM, Rogier $\mathrm{S}$, et al. HIV-testing among female sex workers on the border between Brazil and French Guiana: the need for targeted interventions. Cad Saúde Pública. 2015:31(8):1615-22.

53. Diaz J. A AIDS nas fronteiras do Brasil: diagnóstico estratégico da situação da epidemia de AIDS e doenças sexualmente transmissíveis nas fronteiras do Brasil. Ministério da Saude. Coleção DST/AIDS - Série Estudos, Pesquisas e Avaliação. 2003;

54. Rapport Morlat 2016: Des nouveautés dans la prise en charge des personnes vivant avec le VIH I Vih.org [Internet]. [cited 2017 Jan 11]. Available from: http://vih.org/20161019/rapport-morlat-2016-nouveautesprise-en-charge-personnes-vivant-vih/138637

55. Brazil Ministry of Health: National Department of STD, Aids and Viral Hepatitis. Boletim Epidemiológico AIDS/DST [Internet]. Brasilia; 2015. Report No.: ano IV, Nº1. Available from: http://www.aids.gov.br/sites/default/files/ anexos/publicacao/2015/58534/boletim_aids_11_2015_web_pdf_19105.pdf. Accessed 23 Apr 2017

56. Bulletin d'information trimestrielle du Corevih. COREVIH Guyane; 2016. Report No.: 25. http://www.ch-cayenne.fr/IMG/pdf/bulletin_no25.pdf.

57. Brazil Ministry of Health: National department of STD, Aids and viral hepatitis. Boletim Epidemiológico AIDS/DST. Brasilia; 2013. Report No.: 1.

58. World Health Organization. Global leprosy update, 2015; 2016. p. 405-20. Report No.: 91

59. Domergue V, Clyti E, Sainte-Marie D, Huber F, Marty C, Couppié P. La lèpre en Guyane française: étude rétrospective de 1997 à 2006. Médecine Trop. 2008;68:33-7.

60. Cardoso TBA. Le mercure en Guyane française : synthèse des études d'imprégnation et d'impact sanitaires menées de 1994 à 2005. Bull Epidémiologique Hebd - BEH. 2010;13:118-20.

61. Lormée N. Infections sexuellement transmissibles dans une communauté d'orpailleurs à St Élie, Guyane française. Paris V: Université René Descartes; 2005

62. Kaji A, Thi SS, Smith T, Charunwatthana P, Nosten FH. Challenges in tackling tuberculosis on the Thai-Myanmar border: findings from a qualitative study with health professionals. BMC Health Serv Res [Internet]. 2015 Jun [cited 2017 Jan 4];15(1). Available from: http://bmchealthservres.biomedcentral. com/articles/10.1186/s12913-015-1129-0

63. Zhou G, Lo E, Zhong D, Wang X, Wang Y, Malla S, et al. Impact of interventions on malaria in internally displaced persons along the ChinaMyanmar border: 2011-2014. Malar J. 2016;15:471.

64. Lu Y, Qin L. Healthy migrant and salmon bias hypotheses: a study of health and internal migration in China. Soc Sci Med 1982. 2014 Feb;102:41-8.

65. Diaz CJ, Koning SM, Martinez-Donate AP. Moving beyond Salmon bias: Mexican return migration and health selection. Demography. 2016 Dec;53(6):2005-30.
66. Heraud JM. First case of yellow fever in French Guiana since 1902. Emerg Infect Dis. 1999 Jun;5(3):429-32.

67. Weine SM, Kashuba AB. Labor migration and HIV risk: a systematic review of the literature. AIDS Behav. 2012 Aug:16(6):1605-21.

68. Jolivet A, Cadot E, Florence S, Lesieur S, Lebas J, Chauvin P. Migrant health in French Guiana: Are undocumented immigrants more vulnerable? BMC Public Health [Internet]. 2012 Dec [cited 2016 Dec 19];12(1). Available from: http://bmcpublichealth.biomedcentral.com/articles/10.1186/1471-2458-12-53

69. Jolivet A, Florence S, Lebas J, Chauvin P. Migration, health, and care in French overseas territories. Lancet. 2010 Nov;376(9755):1827-8.

70. Ministério da Saude. Malárianasfronteiras e importadade outrospaíses [Internet]. Brasilia; 2016. Available from: www.saude.gov.br/malaria

\section{Submit your next manuscript to BioMed Central and we will help you at every step:}

- We accept pre-submission inquiries

- Our selector tool helps you to find the most relevant journal

- We provide round the clock customer support

- Convenient online submission

- Thorough peer review

- Inclusion in PubMed and all major indexing services

- Maximum visibility for your research

Submit your manuscript at www.biomedcentral.com/submit 